\title{
Interventions to Support Social Interaction in Children with Autism Spectrum Disorders: A Systematic Review of Single Case Studies
}

\author{
Jennifer Ozuna \\ Alexis Mavridis \\ Brittany L. Hott \\ Texas A\&M University-Commerce
}

\begin{abstract}
Social interaction is a core deficit in individuals with autism spectrum disorder (ASD). Therefore, parents and teachers need effective interventions to support students with ASD. This synthesis provides a quantitative analysis of single-subject studies that examine interventions to support social interactions in children with ASD. Results suggest that pivotal response treatment (PRT), Social Stories ${ }^{T M}$, peer-mediated strategies, and video modelling are promising interventions to support social interaction. Limitations, implications for practice, and suggestions for future research are discussed.
\end{abstract}

Autism spectrum disorder (ASD) is characterized by core deficits in communication and in social interaction and by repetitive behaviors. ASD affects 1 in 68 children, which is a 23\% increase from 2009 (Centers for Disease Control and Prevention, 2014). According to the Diagnostic and Statistical Manual of Mental Disorders, 5th Edition (DSM-5; American Psychiatric Association [APA], 2013), one of the defining characteristics of ASD is a deficit in social communication and interaction across multiple settings. Impairments in social interaction can be identified as lack of joint attention or an inability to respond to or initiate interactions with others, and as features of nonverbal communication such as failure to make eye contact (APA, 2013). Examples of joint attention include a mutual engagement in the same activity and shared interest with another person. Responding includes answering questions, requests, or comments by others. Initiating social interactions would be asking someone to play, greeting others, or 
making comments without prompts. Students are eligible to receive special education and related services under the Individuals with Disabilities Education Act (IDEA) ASD category if "a developmental disability significantly affecting verbal and nonverbal communication and social interaction, generally evident before age three" significantly impacts educational progress (IDEA, 34 CFR $\S 300.8$ (c)(1)(i-iii), 2004).

The ability to interact with others is vital skill necessary throughout life; therefore, it is imperative that interventions are implemented as early as possible (Corsello, 2005). A long-standing body of research indicates that children with autism who receive early intervention fair better than those who receive interventions later in life (Fenske, Zalenski, Krantz, \& McClannahan, 1985). With the increase in prevalence of ASD and with the inclusion of children with disabilities in the general education setting, it is important that parents and teachers are aware of and utilize effective, evidence-based interventions. The development of evidence-based practices in special education can be difficult. Odom et al. (2005) explained that due to the complex nature of special education (such as variability in participants within similar disorders, a variety of educational settings, and low prevalence rates in certain disabilities) methodologies that necessitate a group design, random assignments, or large quantities of participants in order to "build the power of the analysis may be very difficult or not feasible" (p. 140). Single-subject design is a methodology well suited to special education research, as it places emphasis on the individual, is practical in applied settings, allows for the testing of behavioral theories, and is cost-effective (Horner et al., 2005). Horner et al. (2005) defined evidence-based practice in single-subject research as those studies which operationally define practice, context, and outcomes, are implemented with fidelity, are functionally related to outcome change; and demonstrate experimental control. In addition, the standard for evidence-based practice also suggests at least five documented, peer-reviewed, single-subject studies with a minimum of 20 total participants, and replicated by at least three researchers in different locations.

In 2009, Wang and Spillane conducted a meta-analysis of evidence-based interventions to support skills in children with autism. The outcome of their study has identified Social Stories ${ }^{\mathrm{TM}}$, peer-mediated strategies, and video modelling as meeting the criteria for evidence-based interventions. Further, Odom, Klingenberg, Rogers, \& Halton (2010) provided a synthesis of evidence-based interventions for students with autism spectrum disorders defining key characteristics of effective interventions. Gray (2011) developed Social Stories ${ }^{\mathrm{TM}}$ as an intervention to help individuals with autism understand expectations and events in a specific manner that is easily understood. Typically, Social Stories $^{\mathrm{TM}}$ are written in first person from the perspective of the target individual, describe social situations, and aid in expected behavior. Peer mediation involves either training peers to work alone with individuals with autism or training peers and individuals with autism to interact together during social engagements (Banda \& Hart, 2010). Video modelling is an intervention that consists of the target individual observing a video depicting peers, adults, or the child demonstrating expected behavior (Litras, Moore, \& Anderson, 2010). While pivotal response treatment (PRT) is not listed as an evidencebased intervention in the meta-analysis conducted by Wang \& Spillane (2009), PRT meets the criteria for evidence-based intervention according to the National Professional Development Center on Autism Spectrum Disorders (2010). Pivotal behaviors are those 
that are required for daily functioning, such as social initiations, self-management, responsivity to multiple cues, and motivation. Specific PRT procedures include choice, task acquisition, and using natural reinforcers as a way to increase motivation to learn (Koegel Autism Consultants, n.d.).

This synthesis provides a quantitative analysis of single-subject studies that examine interventions to support social interaction in young children with ASD. The following research questions are addressed:

1. Which studies conducted in the last five years offer evidence-based interventions to support social interaction for children in preschool and elementary schools?

2. Which interventions are most effective in increasing social interaction in children with ASD?

3. Are there any effective interventions that have yet to meet the evidence-based criteria, but are worth future evaluation?

\section{Methods}

Studies were reviewed for the present synthesis according to the following guidelines. First, an electronic search was carried out for peer-reviewed journal articles published between 2009 and 2013 in the following databases: Education Research Complete, ERIC, Psychology and Behavioral Sciences Collection, PsycINFO, ScienceDirect, and Social Sciences Citation Index. Next, a manual search of the following journals was conducted: Journal of Applied Behavior Analysis, Exceptional Children, Education and Training in Developmental Disabilities, Focus on Autism and Other Developmental Disabilities, Journal of Autism and Developmental Disorders, and Research in Autism Spectrum Disorders. A combination of the following search terms was used in both database and journal searches: autism, social skills, intervention, Social Stories $^{\mathrm{TM}}$, pivotal response, peer-mediated, peer modelling, and video modelling.

Studies were selected for the synthesis based on the following criteria: (a) The sample study included participants between the ages of 3 and 12 and/or in preschool through Grade 5. For the purpose of examining early intervention practices, interventions designed for adolescents or adults were excluded. (b) The interventions were conducted in applied settings, such as home or school. Interventions carried out in clinics or treatment centres were excluded from this review. (c) The interventions were designed to increase social interaction. Examples of social interaction include joint attention, requesting or responding, initiating interactions, sharing, and showing affection. Studies were excluded if the interventions were designed to target behaviors unrelated to increasing social interaction such as restrictive behaviors, alternative and augmentative communication, or on-task behavior. (d) The studies were published in peer-reviewed journals between 2009 and 2013, i.e., since the meta-analysis published by Wang \& Spillane (2009). (e) The studies were published in English. Studies published in any language other than English were excluded. (f) The studies utilized a single-subject design. Case studies, qualitative studies, and studies using group designs were excluded.

Single-subject studies were chosen if they met the before-mentioned criteria, implemented a design such as multiple-baseline or alternating treatment, used a graphical 
display to chart data collection points (used to calculate the percentage of nonoverlapping data [PND] and the percentage of data exceeding the median [PEM] for the purpose of measuring the effectiveness of the intervention), and operationally defined the independent variables, dependent measures, and procedures (needed for coding purposes). A total of 16 articles met the criteria for the synthesis.

\section{Coding Procedures}

A coding sheet was developed using the quality indicators listed by Horner et al. (2005). Each journal article meeting criteria was coded for research design method, independent and dependent variables, setting, participants, reliability, fidelity, and results from the research. The effectiveness of the intervention was determined by calculating PND and PEM.

PND is a process for determining one measure of treatment effect in single subject studies. It is calculated by dividing the number of intervention data points exceeding the highest number in the baseline by the total number of intervention data points, and multiplying by 100 (Scruggs, Mastropieri, \& Casto, 1987). PND values range from 0 to $100 \%$. A value of $50-70 \%$ indicates an intervention with questionable effectiveness, 70 $90 \%$ is considered fairly effective, and values greater than $90 \%$ indicate an intervention that is highly effective. Some limitations with PND include outlying data distorting the overall effectiveness, or a trend developing during the baseline phase that results in a false positive effect (Allison \& Gorman, 1993). Nevertheless, PND is effective in most cases, simple to calculate, and easy to understand (Mastropieri \& Scruggs, 1986; Scruggs \& Mastropieri, 2013).

PEM is another method for calculating treatment effect in single-subject studies. PEM is obtained by identifying the median data point in the baseline phase, counting every data point above the median baseline number, and dividing the number of points above the median baseline by the total number of intervention data points. PEM values range from 0 to 1 . A score of $0-0.7$ is considered ineffective, $0.7-0.9$ is moderately effective, and 0.9-1 is a highly effective intervention (Ma, 2006). PEM is a solution for those studies that contain outliers in baseline data and, like the PND, is easy to calculate and understand.

The first author coded all of the articles and calculated the PND and PEM. The second author randomly selected $50 \%$ of the articles included in the review, coded them, and calculated the PND and PEM. Inter-rater reliability was calculated by taking the number of agreements, dividing by the number of disagreements plus agreements, and multiplying by 100 for a percentage (Alberto \& Troutman, 2012).

\section{Results}

In all, 1001 articles were located in the preliminary searches. Upon further evaluation, 16 studies met the criteria for the current synthesis. The studies were sorted by the following independent variables: peer-mediated $(N=3)$, PRT $(N=4)$, Social Stories $^{\mathrm{TM}}(N=3)$, video modelling $(N=2)$, and others $(N=4)$. See Appendix A for a summary of study results. 
The studies included 46 participants ( 36 males and 10 females) ranging in age from 3 to 11 years, with a mean age of 5.5 years. Twenty-seven of the participants were diagnosed with autism ranging from mild to severe, sixteen had an autism spectrum disorder (ASD), and three were diagnosed with Asperger's disorder. There were a variety of settings in the studies. Ten interventions were conducted in classrooms and/or school cafeterias, five took place in homes, and one was conducted on a school playground. The single-subject studies in this meta-analysis included two that utilized an alternating treatments design, one used a withdrawal design, two used a multiple-probe design, and the remaining eleven applied a multiple-baseline design. Reliability was reported for all 16 studies, and ranged from 81 to $100 \%$. Fidelity was measured for 10 studies and ranged from 81.6 to $100 \%$. Three studies reported administering a checklist to ensure fidelity, and the remaining three did not measure fidelity. The dependent measures were various forms of social interaction, such as joint attention (e.g., sharing, engagement, maintaining interaction, and two-way play), initiating interaction (e.g., verbal greetings, inviting to play, and requesting an activity), responding, and eye contact. Most of the studies addressed more than one dependent measure. The results were measured as highly effective, moderately effective, fairly effective, questionable effectiveness, or not effective based on the PND and PEM calculations. In all, four interventions were considered not effective or of questionable effectiveness, and 12 were considered fairly to highly effective. The inter-rater reliability for the coding and calculations of the PND and PEM measured $100 \%$.

In order to determine the most effective intervention for each dependent measure, a graph was constructed comparing the effectiveness of interventions designed to support the various forms of social interaction (i.e., joint attention, responding, eye contact, and initiating interaction). The results of each comparison are illustrated in Appendix B. Interventions using PRT boasted the highest effectiveness rating in all four studies, with all considered highly effective. One peer-mediated intervention was considered highly effective (Katz \& Girolametto, 2013), one was not effective (Banda \& Hart, 2010), and one had mixed results ranging from not effective in initiating joint attention, but highly effective in responding (Ferraioli, 2011). Out of the three Social Stories ${ }^{\mathrm{TM}}$ interventions, two were considered fairly to highly effective (Litras et al., 2010; Reichow \& Sabornie, 2009), while one was not effective (Hanley-Horchdorfer, Bray, Kehle, \& Elinoff, 2010). Two interventions tested the effects of video modelling. One was highly effective (Boudreau \& Harvey, 2013), and the other, which compared video to in-vivo modelling, was not effective in increasing social interaction (Wilson, 2012). The interventions labelled as "others" varied in outcomes, but were mostly highly effective. One intervention using social cue cards (Caballero \& Connell, 2010) had the highest effectiveness rating, and two others, concept mastery routines (Laushey, Heflin, Shippen, Alberto, \& Frederick, 2009) and pre-linguistic milieu teaching (Franco, Davis, \& Davis, 2013), were fairly to highly effective. The intervention that coached teachers in naturalistic teaching strategies to increase social interaction was not effective in increasing social interaction in children with ASD (Meadan, Ostrosky, Zaghlawan, \& Yu, 2012). Twelve of the sixteen studies included follow-up or maintenance results. In all twelve studies, the follow-up or maintenance results were similar to the intervention results. Only five of the sixteen studies reported generalization results. In all five studies, 
the target behaviors were generalized in other settings. See Appendix C for a summary of follow-up, maintenance, and generalization results.

\section{Discussion}

The results indicate that PRT is the most effective evidence-based intervention designed to support social interaction in children with ASD. This could be due to the highly motivating way in which PRT is implemented, such as using high-interest items to motivate the participant to comply with directives. Other studies examining the use of PRT have found similar results in increasing joint attention and initiating social interactions (Jones, Carr, \& Feeley, 2006; Pierce \& Schreibman, 1997; Whalen \& Schreibman, 2003). Social Stories ${ }^{\mathrm{TM}}$ is an intervention often used in schools by teachers, possibly because of the simplicity in creating stories (Reynhout \& Carter, 2008), but is one that has had mixed results in other studies, with the most effective results occurring in interventions designed for children with average to above average cognitive and language skills (Kokina \& Kern, 2010). The results in the current synthesis were mixed as well with two studies reporting fair to high effectiveness ratings, and one that was considered not effective. These findings suggest that while Social Stories ${ }^{\mathrm{TM}}$ are effective in many cases, one must use caution when choosing this intervention. Gray (2011) recommends following established guidelines she set in order to promote effectiveness. Peer-mediation is an intervention that has been used for years, and many researchers have seen positive results, although some report minimal gains in peer imitation and social interaction (Garfinkle \& Schwartz, 2002; Odom \& Strain, 1986). The current results were also mixed, with one intervention reporting results that indicated a high effectiveness; a second that was not effective; and a third that was effective in responding, but not in initiating joint attention. Laushey \& Heflin (2000) stated that peer-mediation may be most effective when training both peers and children with autism together, rather than peers alone. While video modelling was cited by Wang \& Spillane (2009) as the only intervention to meet evidence-based criteria as well as establish high effectiveness, the results of their study were mixed. In the study that was considered not effective, Wilson (2012) indicated the reason could be due to the complexity of one participant's medical diagnosis. This could suggest that video modelling is effective in most cases in increasing social interaction in children with autism, as seen in many other studies (e.g., Bellini \& Akullian, 2007; Delano, 2007), but may not be as effective in more severe cases. Several interventions, such as social cue cards, pre-linguistic milieu teaching, and concept mastery routines, were effective and show promise, but more research is necessary before being labelled as an evidence-based intervention.

\section{Limitations}

A limitation of the current synthesis is that the studies included did not describe the participants according to the new defining criteria of ASD as outlined in the DSM-5. The revised definition includes three levels of severity and a related disorder, social (pragmatic) communication disorder (APA, 2013). Parents, teachers, and practitioners may have difficulty matching interventions to the needs of a newly diagnosed child. Another limitation is that studies that included interventions for children younger than 3 
years old were excluded. The present synthesis sought to compare interventions for preschool and elementary school students; but due to the increase in ASD prevalence rate and the importance of early intervention, a synthesis including studies with interventions specifically designed for children aged birth to 2 years may be beneficial.

\section{Implications and Future Research}

As students with disabilities are mainstreamed into the general education setting, it is more important than ever for general education teachers to be aware of effective, evidence-based interventions. Students in general education settings often work in cooperative learning groups, making the ability to interact socially an essential skill. This synthesis provides a quantitative analysis of recent studies specifically related to increasing social interaction, which is relevant to today's classroom. Also, research has shown that providing early interventions for one core deficit of ASD, such as social interaction, can improve other deficits as well (Koegel, Vernon, \& Koegel, 2009). It can be concluded that the effective evidence-based interventions listed in this synthesis can have a positive effect on other deficits associated with ASD.

It would be helpful to include additional information about participants in light of the revised DSM criteria. In doing this, practitioners, parents, and teachers may be able to closely match interventions to children with a similar diagnosis. Also, since the importance for early intervention has been noted, future research in interventions for children under age 3 would be prudent. Finally, this synthesis provided a comparative analysis of interventions for specific areas of social interaction. Future comparative studies would be worth conducting in order to see if the findings are similar.

\section{Conclusion}

ASD is a lifelong disorder that can improve with early intervention. With an increase in prevalence and the call for evidence-based practice, parents and teachers are continually looking for effective interventions to help children with ASD. One must use caution, however, when choosing interventions because not all interventions are suited for every child with ASD. Some have shown to be more effective with children functioning at higher levels, while other interventions work well for children at various levels of functioning. This synthesis provides a review of recent studies that include interventions to support social interaction. A comparative analysis is also provided in order to assist practitioners, parents, and teachers in choosing the most effective, evidence-based intervention.

\section{References}

References marked with an asterisk indicate studies included in the meta-analysis.

Alberto, P. A., \& Troutman, A. C. (2012). Applied behavior analysis for teachers (9th ed.). Upper Saddle River, NJ: Pearson Education.

Allison, D. B., \& Gorman, B. S. (1993). Calculating effect sizes for meta-analysis: The case of the single case. Behaviour Research and Therapy, 31(6), 621-631. doi:10.1016/0005-7967 (93)90115-B 
American Psychiatric Association (2013). Diagnostic and statistical manual of mental disorders (5th ed.). Washington, DC: Author.

*Banda, D. R., \& Hart, S. L. (2010). Increasing peer-to-peer social skills through direct instruction of two elementary school girls with autism. Journal of Research in Special Education Needs, 10(2), 124-132. doi:10.1111/j.1471-3802.2010.01149x

Bellini, S., \& Akullian, J. (2007). A meta-analysis of video modeling and video self-modeling interventions for children and adolescents with autism spectrum disorders. Exceptional Children, 73(3), 264-287.

*Boudreau, J., \& Harvey, M. T. (2013). Increasing recreational initiations for children who have ASD using video self-modeling. Education and Treatment of Children (West Virginia University Press), 36(1), 49-60.

*Caballero, A., \& Connell, J. E. (2010). Evaluation of the effects of social cue cards for preschool age children with autism spectrum disorders (ASD). Journal of Behavior Assessment \& Intervention in Children, 1(1), 25-42.

Centers for Disease Control and Prevention (2014). Autism spectrum disorders (ASDs): Data \& statistics. Retrieved from http://www.cdc.gov/ncbddd/autism/data.html

Corsello, C. M. (2005) Early intervention in Autism. Infants and Young Children, 18(2), 74-85.

Delano, M. (2007). Video modeling interventions for individuals with autism. Remedial \& Special Education, 28(1), 33-42.

Fenske E. C., Zalenski, S., Krantz, P. J., \& McClannahan, L. E. (1985). Age at intervention and treatment outcome for autistic children in a comprehensive intervention program. Analysis and Intervention in Developmental Disabilities, 5(1-2), 49-58.

*Ferraioli, S. L. (2011). Teaching joint attention to children with autism through a sibling- mediated behavioral intervention. Behavioral Interventions, 26(4), 261-281.

*Franco, J. H., Davis, B. L., \& Davis, J. L. (2013). Increasing social interaction using prelinguistic milieu teaching with nonverbal school-age children with autism. American Journal of SpeechLanguage Pathology, 22(3), 489-502. doi:10.1044/1058-0360(2012/10- 0103)

Garfinkle, A. N., \& Schwartz, I. S. (2002). Peer initiation: Increasing social interactions in children with autism and other developmental disabilities in inclusive preschool classrooms. Topics in Early Childhood Special Education, 22(1), 26-38.

Gray, C. (2011). What are Social Stories? Retrieved from http://thegraycenter.org/socialstories/what-are-social-stories

*Hanley-Hochdorfer, K., Bray, M. A., Kehle, T. J., \& Elinoff, M. J. (2010). Social Stories to increase verbal initiation in children with autism and Asperger's disorder. School Psychology Review, 39(3), 484-492.

Horner, R. H., Carr, E. G., Halle, J., McGee, G., Odom, S., \& Wolery, M. (2005). The use of singlesubject research to identify evidence-based practice in special education. Counsel for Exceptional Children, 71(2), 165-179.

Individuals with Disabilities Education Act, 34 CFR § 300.8(c)(1)(i-iii), (2004). Retrieved from http://idea.ed.gov/explore/view

Jones, E. A., Carr, E. G., \& Feeley, K. M. (2006). Multiple effects of joint attention intervention for children with autism. Behavior Modification, 30, 782-834.

*Katz, E., \& Girolametto, L. (2013). Peer-mediated intervention for preschoolers with ASD implemented in early childhood education settings. Topics in Early Childhood Special Education, 33(3), 133-143. 
Koegel Autism Consultants (n.d.). About PRT®. Retrieved from http://www.autismprthelp.com /about-prt.php

*Koegel, L., Kuriakose, S., Singh, A., \& Koegel, R. (2012). Improving generalization of peer socialization gains in inclusive school settings using initiations training. Behavior Modification, 36(3), 361-377.

*Koegel, R. L., Vernon, T. W., \& Koegel, L. K. (2009). Improving social initiations in young children with autism using reinforcers with embedded social interactions. Journal of Autism \& Developmental Disorders, 39(9), 1240-1251. doi:10.1007/s10803-009-0732-5

*Koegel, L. K., Vernon, T. W., Koegel, R. L., Koegel, B. L., \& Paullin, A. W. (2012). Improving social engagement and initiations between children with autism spectrum disorder and their peers in inclusive settings. Journal of Positive Behavior Interventions, 14(4), 220-227.

Kokina, A., \& Kern, L. (2010). Social Story ${ }^{\mathrm{TM}}$ interventions for students with autism spectrum disorders: A meta-analysis. Journal of Autism \& Developmental Disorders, 40(7), 812-826. doi:10.1007/s10803-009-0931-0

Laushey, K. M., \& Heflin, L. J. (2000). Enhancing social skills of kindergarten children with autism through the training of multiple peers as tutors. Journal of Autism and Developmental Disabilities. 30, 183-193.

*Laushey, K., Heflin, L., Shippen, M., Alberto, P., \& Fredrick, L. (2009). Concept mastery routines to teach social skills to elementary school children with high functioning autism. Journal of Autism \& Developmental Disorders, 39(10), 1435-1448. doi:10.1007/s10803-009- 0757-9

*Litras, S., Moore, D., \& Anderson, A. (2010). Using video self-modeled Social Stories to teach social skills to a young child with autism. Autism Research and Treatment, 2010834979. doi:10.1155/2010/834979

Ma, H. (2006). An alternative method for quantitative synthesis of single-subject researches: Percentage of data points exceeding the median. Behavior Modification, 30(5), 598-617.

Mastropieri, M. A., \& Scruggs, T. E. (1986). Early intervention for socially withdrawn children. Journal of Special Education, 19(4), 429-441.

*Meadan, H., Ostrosky, M. M., Zaghlawan, H. Y., \& Yu, S. Y. (2012). Using coaching with preschool teachers to support the social skills of children with and without autism spectrum disorders. International Journal of Early Childhood Special Education, 4(2), 74-94.

National Professional Development Center on Autism Spectrum Disorders (2010). Evidence-based practice: Pivotal response training (PRT). Retrieved from http://autismpdc.fpg.unc.edu /content/pivotal-response-training

Odom, S. L., Brantlinger, E., Gersten, R., Horner, R. H., Thompson, B., \& Harris, K. R. (2005). Research in special education: Scientific methods and evidence-based practices. Exceptional Children, 71(2), 137.

Odom, S. L., Klingenberg, L. C., Rogers, S. J., \& Halton, D. D. (2010). Evidenced-based practices in interventions for children and youth with autism spectrum disorders. Preventing School Failure, 54, 275-282. doi:10.1080/10459881003785506

Odom, S. L., \& Strain, P. S. (1986). A comparison of peer-initiation and teacher-antecedent interventions for prompting reciprocal social interactions of autistic preschoolers. Journal of Applied Behavior Analysis, 19, 58-72.

Pierce, K., \& Schreibman, L. (1997). Multiple peer use of pivotal response training to increase social behaviors of classmates with autism: Results from trained and untrained peers. Journal of Applied Behavioral Analysis, 30, 157-160. 
*Reichow, B., \& Sabornie, E. J. (2009). Brief Report: Increasing verbal greeting initiations for a student with autism via a Social Story intervention. Journal of Autism \& Developmental Disorders, 39(12), 1740-1743. doi:10.1007/s10803-009-0818-4

Reynhout, G., \& Carter, M. (2008). The use of Social Stories by teachers and their perceived efficacy. Research in Autism Spectrum Disorders, 3(1), 232-251. doi:10.1016/j.rasd.2008. 06.003

Scruggs, T. E., \& Mastropieri, M. A. (2013). PND at 25: Past, present, and future trends in summarizing single-subject research. Remedial \& Special Education, 34(1), 9-19. doi:10.1177/0741932512440730

Scruggs, T., Mastropieri, M., \& Casto, G. (1987). The quantitative synthesis of single-subject research: Methodology and validation. Remedial \& Special Education, 8(2), 24-33.

*Vernon, T. (2012). An early social engagement intervention for young children with autism and their parents. Journal of Autism \& Developmental Disorders, 42(12), 2702-2717.

Wang, P., \& Spillane, A. (2009). Evidence-based social skills interventions for children with autism: A meta-analysis. Education and Training in Developmental Disabilities, 44(3), 318-342.

Whalen, C., \& Schreibman, L. (2003). Joint attention training for children with autism using behavior modification procedures. Journal of Child Psychology \& Psychiatry, 44(3), 456-468.

*Wilson, K. (2012). Teaching social-communication skills to preschoolers with autism: Efficacy of video versus in vivo modeling in the classroom. Journal of Autism and Developmental Disorders, 43(8), 1819-1831.

\section{Authors' Note}

Correspondence concerning this article should be addressed to Brittany L. Hott, Department of Psychology, Counseling, and Special Education, Texas A\&M University- Commerce, P.O. Box 3011, Commerce, Texas 75429, U.S.A. Email: brittany.hott@tamuc.edu 


\section{Appendix A: Summary of Interventions to Support Social Interaction in Children with ASD}

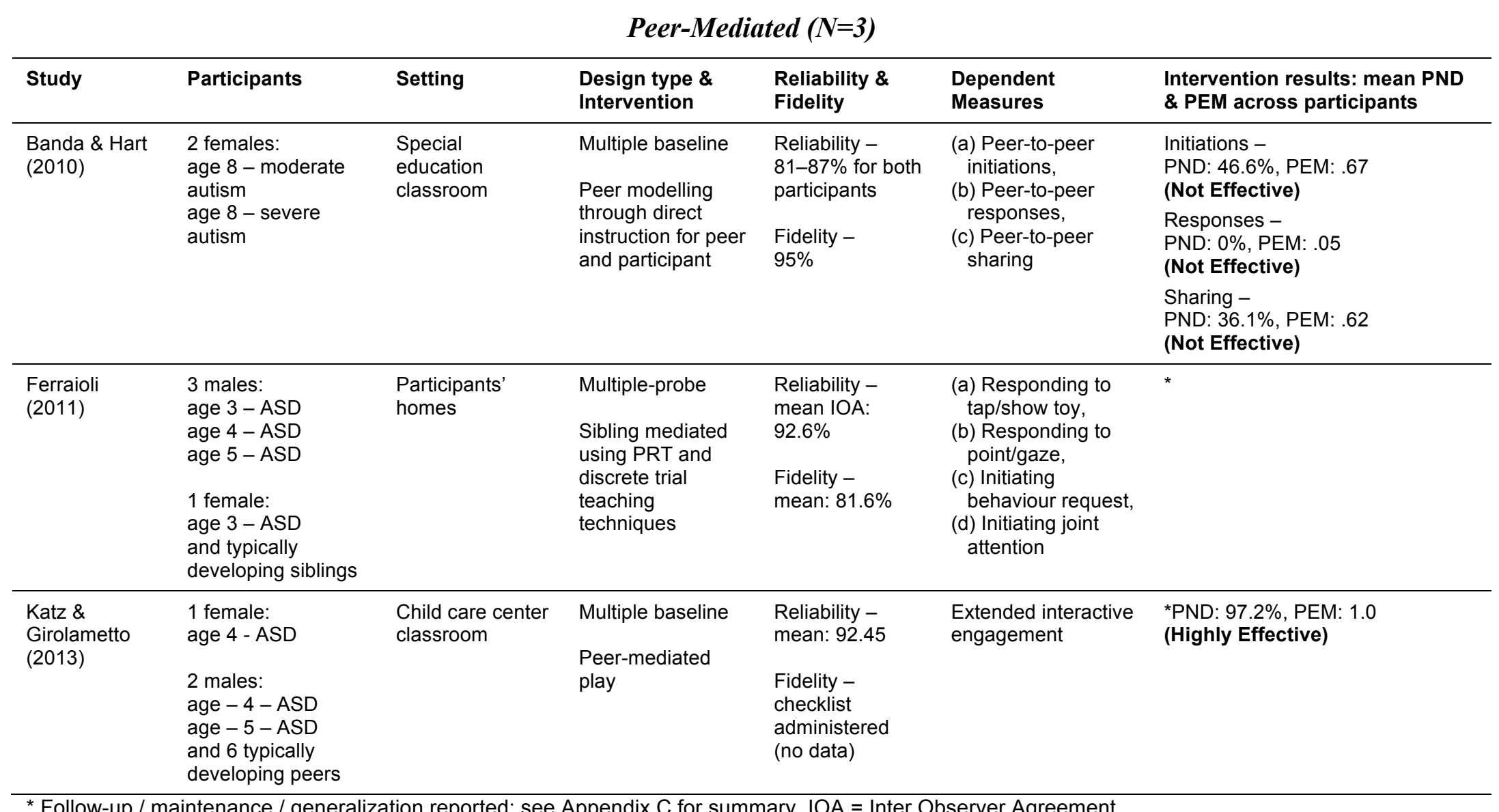




\section{Appendix A, continued}

$\operatorname{PRT}(\mathrm{N}=4)$

\begin{tabular}{|c|c|c|c|c|c|c|}
\hline Study & Participants & Setting & $\begin{array}{l}\text { Design type \& } \\
\text { Intervention }\end{array}$ & $\begin{array}{l}\text { Reliability \& } \\
\text { Fidelity }\end{array}$ & $\begin{array}{l}\text { Dependent } \\
\text { Measures }\end{array}$ & $\begin{array}{l}\text { Intervention results: mean PND } \\
\text { \& PEM across participants }\end{array}$ \\
\hline \multirow[t]{3}{*}{$\begin{array}{l}\text { Koegel, } \\
\text { Kuriakose, et } \\
\text { al. (2012) }\end{array}$} & \multirow{3}{*}{$\begin{array}{l}2 \text { males: } \\
\text { age } 5 \text { - autism } \\
\text { age } 5 \text { - Asperger's } \\
1 \text { female: } \\
\text { age } 6 \text { - autism }\end{array}$} & \multirow[t]{3}{*}{$\begin{array}{l}\text { School } \\
\text { playground } \\
\text { during recess }\end{array}$} & \multirow{3}{*}{$\begin{array}{l}\text { Multiple baseline } \\
\text { Facilitated social } \\
\text { play with initiations } \\
\text { training }\end{array}$} & \multirow{3}{*}{$\begin{array}{l}\text { Reliability - } \\
\text { mean: } 94.5 \% \text {, } \\
\text { Kappa - .89 } \\
\text { Fidelity - } \\
98-100 \% \text { for } \\
\text { all sessions }\end{array}$} & \multirow{3}{*}{$\begin{array}{l}\text { (a) Unprompted } \\
\text { peer-directed } \\
\text { initiations, } \\
\text { (b) Social } \\
\text { engagement, } \\
\text { (c) Affect }\end{array}$} & $\begin{array}{l}\text { *Unprompted initiations - } \\
\text { PND: } 89.6 \% \text {, PEM: } .91 \\
\text { (Highly Effective) }\end{array}$ \\
\hline & & & & & & $\begin{array}{l}\text { *Social engagement - } \\
\text { PND: 100, PEM: } 1.0 \\
\text { (Highly Effective) }\end{array}$ \\
\hline & & & & & & $\begin{array}{l}{ }^{*} \text { Affect }- \\
\text { PND: } 100 \%, \text { PEM: } 1.0 \\
\text { (Highly Effective) }\end{array}$ \\
\hline \multirow[t]{2}{*}{$\begin{array}{l}\text { Koegel et al. } \\
(2009)\end{array}$} & \multirow[t]{2}{*}{$\begin{array}{l}2 \text { males: } \\
\text { age } 3 \text { - autism } \\
\text { age } 3 \text { - autism }\end{array}$} & \multirow[t]{2}{*}{$\begin{array}{l}\text { Participants' } \\
\text { homes }\end{array}$} & $\begin{array}{l}\text { Alternating } \\
\text { treatments }\end{array}$ & $\begin{array}{l}\text { Reliability - } \\
\text { mean: } 85.5 \%\end{array}$ & \multirow{2}{*}{$\begin{array}{l}\text { (a) Self-initiated } \\
\text { social engagement, } \\
\text { (b) Non-verbal } \\
\text { dyadic orienting } \\
\text { (eye-contact), } \\
\text { (c) Affect }\end{array}$} & \\
\hline & & & $\begin{array}{l}\text { PRT with } \\
\text { embedded social } \\
\text { condition }\end{array}$ & $\begin{array}{l}\text { Fidelity - } \\
\text { mean: } 98 \%\end{array}$ & & \\
\hline \multirow[t]{2}{*}{$\begin{array}{l}\text { Koegel, } \\
\text { Vernon, et al. } \\
(2012)\end{array}$} & \multirow[t]{2}{*}{$\begin{array}{l}2 \text { males: } \\
\text { age } 9-A S D \\
\text { age } 10-A S D\end{array}$} & \multirow{2}{*}{$\begin{array}{l}\text { School cafeteria } \\
\text { during and after } \\
\text { lunch (summer } \\
\text { day camp data } \\
\text { for child } 1 \\
\text { excluded) }\end{array}$} & \multirow{2}{*}{$\begin{array}{l}\text { Multiple baseline } \\
\text { High interest } \\
\text { activities and clubs }\end{array}$} & \multirow{2}{*}{$\begin{array}{l}\text { Reliability - } \\
\text { mean: } 97 \% \\
\text { Fidelity - } \\
\text { not measured }\end{array}$} & \multirow{2}{*}{$\begin{array}{l}\text { (a) Engagement } \\
\text { with peers } \\
\text { (b) Unprompted } \\
\text { verbal initiations }\end{array}$} & $\begin{array}{l}\text { Engagement with peers - } \\
\text { PND: } 100 \%, \text { PEM: } 1.0 \\
\text { (Highly Effective) }\end{array}$ \\
\hline & & & & & & $\begin{array}{l}\text { Unprompted verbal initiations - } \\
\text { PND: } 100 \%, \text { PEM: } 1.0 \\
\text { (Highly Effective) }\end{array}$ \\
\hline \multirow[t]{4}{*}{ Vernon (2012) } & \multirow[t]{4}{*}{$\begin{array}{l}1 \text { male: } \\
\text { age } 4 \text { - autism }\end{array}$} & \multirow{4}{*}{$\begin{array}{l}\text { Participant's } \\
\text { home \& } \\
\text { community } \\
\text { places (parks, } \\
\text { school } \\
\text { playgrounds, } \\
\text { etc.) }\end{array}$} & \multirow{4}{*}{$\begin{array}{l}\text { Multiple baseline } \\
\text { PRT with } \\
\text { embedded social } \\
\text { interaction }\end{array}$} & \multirow{4}{*}{$\begin{array}{l}\text { Reliability - } \\
\text { mean: .86, } \\
\text { mean Kappa: } \\
.67\end{array}$} & \multirow{4}{*}{$\begin{array}{l}\text { (a) Eye contact, } \\
\text { (b) Verbal } \\
\text { initiations, } \\
\text { (c) Positive affect, } \\
\text { (d) Synchronous } \\
\text { engagement }\end{array}$} & $\begin{array}{l}\text { *Eye contact - } \\
\text { PND: } 100 \%, \text { PEM: } 1.0 \\
\text { (Highly Effective) }\end{array}$ \\
\hline & & & & & & $\begin{array}{l}\text { *Verbal initiations: } \\
\text { PND: } 93.7 \%, \text { PEM: } 1.0 \\
\text { (Highly Effective) }\end{array}$ \\
\hline & & & & & & $\begin{array}{l}\text { *Positive affect - } \\
\text { PND: } 100 \%, \text { PEM: } 1.0 \\
\text { (Highly Effective) }\end{array}$ \\
\hline & & & & & & $\begin{array}{l}\text { *Synchronous engagement - } \\
\text { PND: } 100 \% \text {, PEM: } 1.0 \\
\text { (Highly Effective) }\end{array}$ \\
\hline
\end{tabular}

* Follow-up / maintenance / generalization reported; see Appendix C for summary

118 Exceptionality Education International, 2015, Vol. 25, No. 2 


\section{Appendix A, continued}

Social Stories $^{T M}(N=3)$

\begin{tabular}{|c|c|c|c|c|c|c|}
\hline Study & Participants & Setting & $\begin{array}{l}\text { Design type \& } \\
\text { Intervention }\end{array}$ & $\begin{array}{l}\text { Reliability \& } \\
\text { Fidelity }\end{array}$ & $\begin{array}{l}\text { Dependent } \\
\text { Measures }\end{array}$ & $\begin{array}{l}\text { Intervention results: mean PND } \\
\& \text { PEM across participants }\end{array}$ \\
\hline $\begin{array}{l}\text { Hanley- } \\
\text { Hochdorfer et } \\
\text { al. (2010) }\end{array}$ & $\begin{array}{l}2 \text { males: } \\
\text { age } 6 \text { - Asperger's } \\
\text { age } 11 \text { - Asperger's } \\
1 \text { female: } \\
\text { age } 9 \text { - autism }\end{array}$ & $\begin{array}{l}\text { School } \\
\text { cafeteria }\end{array}$ & $\begin{array}{l}\text { Multiple baseline } \\
\text { Social Stories }\end{array}$ & $\begin{array}{l}\text { Reliability - } \\
\text { mean: } 98 \% \\
\text { Fidelity - } \\
97.3 \%\end{array}$ & $\begin{array}{l}\text { (a) Verbal initiations, } \\
\text { (b) Contingent } \\
\text { response }\end{array}$ & $\begin{array}{l}\text { *Verbal initiations - } \\
\text { PND: } 18.3 \%, \text { PEM: } .20 \\
\text { (Not Effective) } \\
{ }^{*} \text { Contingent response - } \\
\text { PND: } 32.5 \%, \text { PEM: } .37 \\
\text { (Not Effective) }\end{array}$ \\
\hline \multirow[t]{3}{*}{$\begin{array}{l}\text { Litras et al. } \\
\text { (2010) }\end{array}$} & \multirow[t]{3}{*}{$\begin{array}{l}1 \text { male: } \\
\text { age } 3-\text { mild-moderate } \\
\text { ASD }\end{array}$} & \multirow[t]{3}{*}{$\begin{array}{l}\text { Participant's } \\
\text { home }\end{array}$} & \multirow{3}{*}{$\begin{array}{l}\text { Multiple baseline } \\
\text { Video self- } \\
\text { modelling Social } \\
\text { Story }\end{array}$} & $\begin{array}{l}\text { Reliability - } \\
\text { mean: } 95 \%\end{array}$ & \multirow{3}{*}{$\begin{array}{l}\text { (a) Greeting, } \\
\text { (b) Inviting to play, } \\
\text { (c) Contingent } \\
\text { responding }\end{array}$} & $\begin{array}{l}\text { *Greeting - } \\
\text { PND: } 82.3 \% \text {, PEM: } 82 \\
\text { (Fairly to Moderately Effective) }\end{array}$ \\
\hline & & & & $\begin{array}{l}\text { Fidelity - } \\
\text { checklist was } \\
\text { provided to }\end{array}$ & & $\begin{array}{l}\text { *Inviting to play - } \\
\text { PND: } 90 \%, \text { PEM: } 1.0 \\
\text { (Highly Effective) }\end{array}$ \\
\hline & & & & $\begin{array}{l}\text { parents } \& \\
\text { monitored, but } \\
\text { not measured }\end{array}$ & & $\begin{array}{l}{ }^{*} \text { Contingent responding - PND: } \\
75 \%, \text { PEM: } 1.0 \\
\text { (Fairly to Highly Effective) }\end{array}$ \\
\hline \multirow[t]{2}{*}{$\begin{array}{l}\text { Reichow \& } \\
\text { Sabornie } \\
(2009)\end{array}$} & \multirow[t]{2}{*}{$\begin{array}{l}1 \text { male: } \\
\text { age } 11 \text { - autism }\end{array}$} & \multirow[t]{2}{*}{ Classroom } & \multirow[t]{2}{*}{$\begin{array}{l}\text { Withdrawal design } \\
\text { Social Stories \& } \\
\text { visual cue cards }\end{array}$} & $\begin{array}{l}\text { Reliability - } \\
\text { mean: } 100 \% \\
\text { Fidelity - not } \\
\text { measured }\end{array}$ & \multirow[t]{2}{*}{$\begin{array}{l}\text { (a) Verbal greeting } \\
\text { initiation with } \\
\text { Social Story, } \\
\text { (b) Verbal greeting } \\
\text { initiation with cue } \\
\text { cards }\end{array}$} & $\begin{array}{l}\text { *Social Story - } \\
\text { Total initiations to adults - } \\
\text { PND: } 100 \% \text {, PEM: } 1.0 \\
\text { Initiations to peers only - } \\
\text { PND: } 84.6 \%, \text { PEM: } .84 \\
\text { (Fairly to Highly Effective) }\end{array}$ \\
\hline & & & & & & $\begin{array}{l}{ }^{*} \text { Cue cards - } \\
\text { Total initiations to adults - } \\
\text { PND: } 100 \%, \text { PEM: } 1.0 \\
\text { Initiations to peers - } \\
\text { PND: } 100 \%, \text { PEM: } 1.0 \\
\text { (Highly Effective) }\end{array}$ \\
\hline
\end{tabular}

\footnotetext{
* Follow-up / maintenance / generalization reported; see Appendix C for summary
} 


\section{Appendix A, continued}

Video Modelling $(N=2)$

\begin{tabular}{|c|c|c|c|c|c|c|}
\hline Study & Participants & Setting & $\begin{array}{l}\text { Design type \& } \\
\text { Intervention }\end{array}$ & $\begin{array}{l}\text { Reliability \& } \\
\text { Fidelity }\end{array}$ & $\begin{array}{l}\text { Dependent } \\
\text { Measures }\end{array}$ & $\begin{array}{l}\text { Intervention results: mean PND \& } \\
\text { PEM across participants }\end{array}$ \\
\hline $\begin{array}{l}\text { Boudreau \& } \\
\text { Harvey (2013) }\end{array}$ & $\begin{array}{l}\text { Participants: } \\
3 \text { males: } \\
\text { ages } 4-7 \text { - ASD } \\
\text { Peers: } \\
3 \text { students with ASD } \\
\& 3 \text { students w/o } \\
\text { ASD }\end{array}$ & $\begin{array}{l}\text { School - } \\
\text { conference room } \\
\text { and playroom }\end{array}$ & $\begin{array}{l}\text { Multiple baseline } \\
\text { Video self- } \\
\text { modelling }\end{array}$ & $\begin{array}{l}\text { Reliability - } \\
\text { mean: } 88.7 \% \text {, } \\
\text { Kappa: } .98 \\
\text { Fidelity - not } \\
\text { measured }\end{array}$ & $\begin{array}{l}\text { Social initiations to } \\
\text { peers }\end{array}$ & $\begin{array}{l}\text { *PND: } 94.4 \%, \text { PEM: } 1.0 \\
\text { (Highly Effective) }\end{array}$ \\
\hline \multirow[t]{7}{*}{ Wilson (2012) } & \multirow{7}{*}{$\begin{array}{l}2 \text { males: } \\
\text { age } 5 \text { - autism } \\
\text { age } 3 \text { - autism } \\
2 \text { females: } \\
\text { age } 4 \text { - autism } \\
\text { age } 4 \text { - autism }\end{array}$} & \multirow[t]{7}{*}{ Classroom } & \multirow{7}{*}{$\begin{array}{l}\text { Alternating } \\
\text { treatment } \\
\text { Video and in-vivo } \\
\text { modelling }\end{array}$} & \multirow{7}{*}{$\begin{array}{l}\text { Reliability - } \\
\text { mean: } 92.5 \% \\
\text { Fidelity - } \\
\text { mean: } 96 \%\end{array}$} & \multirow{7}{*}{$\begin{array}{l}\text { (a) Requesting an } \\
\text { object, } \\
\text { (b) Joint attention, } \\
\text { (c) Social } \\
\text { interaction }\end{array}$} & $\begin{array}{l}\text { Video modelling - } \\
{ }^{*} \text { Requesting - } \\
\text { PND: } 30.7 \% \text {, PEM: } .38 \\
\text { (Not Effective) }\end{array}$ \\
\hline & & & & & & $\begin{array}{l}\text { *Joint attention - } \\
\text { PND: 0\%, PEM: .25 } \\
\text { (Not Effective) }\end{array}$ \\
\hline & & & & & & $\begin{array}{l}\text { *Social interaction - } \\
\text { PND: } 50.5 \%, \text { PEM: } .59 \\
\text { (Questionable Effectiveness) }\end{array}$ \\
\hline & & & & & & In-vivo modelling: \\
\hline & & & & & & $\begin{array}{l}{ }^{*} \text { Requesting - } \\
\text { PND: } 61.5 \% \text {, PEM: } .76 \\
\text { (Questionable Effectiveness) }\end{array}$ \\
\hline & & & & & & $\begin{array}{l}\text { *Joint attention - } \\
\text { PND: 0\%, PEM: } .30 \\
\text { (Not Effective) }\end{array}$ \\
\hline & & & & & & $\begin{array}{l}\text { *Social interaction - } \\
\text { PND: } 26 \%, \text { PEM: .39 } \\
\text { (Not Effective) }\end{array}$ \\
\hline
\end{tabular}

* Follow-up / maintenance / generalization reported; see Appendix C for summary 


\section{Appendix A, continued}

Others $(N=4)$

\begin{tabular}{|c|c|c|c|c|c|c|}
\hline Study & Participants & Setting & $\begin{array}{l}\text { Design type \& } \\
\text { Intervention }\end{array}$ & $\begin{array}{l}\text { Reliability \& } \\
\text { Fidelity }\end{array}$ & $\begin{array}{l}\text { Dependent } \\
\text { Measures }\end{array}$ & $\begin{array}{l}\text { Intervention results: mean } \\
\text { PND \& PEM across } \\
\text { participants }\end{array}$ \\
\hline $\begin{array}{l}\text { Caballero \& } \\
\text { Connell (2010) }\end{array}$ & $\begin{array}{l}3 \text { males: } \\
\text { age } 4-\text { ASD } \\
\text { age } 4-\text { ASD } \\
\text { age } 5-\text { ASD }\end{array}$ & $\begin{array}{l}\text { Participants' } \\
\text { school and home }\end{array}$ & $\begin{array}{l}\text { Multiple baseline } \\
\text { Social cue cards }\end{array}$ & $\begin{array}{l}\text { Reliability - } \\
\text { mean: } 100 \% \\
\text { Fidelity - mean: } \\
100 \%\end{array}$ & $\begin{array}{l}\text { Child 1: Persisting for } \\
\text { attention } \\
\text { Child 2: Defending } \\
\text { self } \\
\text { Child 3: Peer initiation }\end{array}$ & $\begin{array}{l}\text { *Independent engagement in } \\
\text { target behaviours: PND: } 100 \% \text {, } \\
\text { PEM: } 1.0 \\
\text { (Highly Effective) }\end{array}$ \\
\hline $\begin{array}{l}\text { Franco et al. } \\
(2013)\end{array}$ & $\begin{array}{l}5 \text { males with } \\
\text { moderate to severe } \\
\text { autism } \\
\text { ages } 5-8 \\
1 \text { female: } \\
\text { age } 7 \text { - moderate } \\
\text { to severe autism }\end{array}$ & $\begin{array}{l}\text { Participants' } \\
\text { homes }\end{array}$ & $\begin{array}{l}\text { Multiple baseline } \\
\text { Pre-linguistic } \\
\text { Milieu Teaching }\end{array}$ & $\begin{array}{l}\text { Reliability - } \\
\text { mean: } 91.5 \% \\
\text { Fidelity - mean: } \\
98 \%\end{array}$ & $\begin{array}{l}\text { (a) Maintaining social } \\
\text { interaction, } \\
\text { (b) Initiating social } \\
\text { interaction }\end{array}$ & $\begin{array}{l}\text { *Maintaining social interaction - } \\
\text { PND: } 95.2 \%, \text { PEM: } 1.0 \\
\text { (Highly Effective) } \\
\text { *Initiating social interaction - } \\
\text { PND: } 98.8 \%, \text { PEM: .98 } \\
\text { (Highly Effective) }\end{array}$ \\
\hline $\begin{array}{l}\text { Laushey et al. } \\
\text { (2009) }\end{array}$ & $\begin{array}{l}4 \text { males: } \\
\text { 1st grader - autism } \\
\text { 2nd grader - } \\
\text { autism } \\
\text { 4th grader - autism } \\
\text { 4th grader - autism }\end{array}$ & $\begin{array}{l}\text { Participants' } \\
\text { school: cafeteria } \\
\text { and classrooms }\end{array}$ & $\begin{array}{l}\text { Multiple baseline } \\
\text { Concept mastery } \\
\text { routines }\end{array}$ & $\begin{array}{l}\text { Reliability - } \\
\text { mean: } 91 \% \\
\text { Fidelity - } \\
\text { checklist } \\
\text { administered and } \\
\text { it was noted that } \\
\text { all steps were } \\
\text { followed }\end{array}$ & $\begin{array}{l}\text { (a) Responding to } \\
\text { questions, } \\
\text { (b) Initiating } \\
\text { interactions, } \\
\text { (c) Reading facial } \\
\text { expressions }\end{array}$ & $\begin{array}{l}\text { *Responding to questions - } \\
\text { PND: } 87.4 \% \text {, PEM: } 1.0 \\
\text { (Fairly to Highly Effective) } \\
{ }^{*} \text { Initiating interactions - PND: } \\
95.8 \%, \text { PEM: } 1.0 \\
\text { (Highly Effective) } \\
\text { *Reading facial expressions - } \\
\text { PND: } 100 \%, \text { PEM: } 1.0 \\
\text { (Highly Effective) }\end{array}$ \\
\hline $\begin{array}{l}\text { Meadan et al. } \\
(2012)\end{array}$ & $\begin{array}{l}3 \text { males: } \\
\text { age } 4 \text { - autism } \\
\text { age } 3 \text { - autism } \\
\text { age } 4 \text { - autism }\end{array}$ & $\begin{array}{l}\text { Preschool during } \\
\text { choice/centre } \\
\text { time }\end{array}$ & $\begin{array}{l}\text { Multiple-probe } \\
\text { Coaching } \\
\text { teachers to } \\
\text { support social } \\
\text { skills }\end{array}$ & $\begin{array}{l}\text { Reliability - } \\
\text { mean: } 81.5 \% \\
\text { Fidelity - mean: } \\
100 \%\end{array}$ & $\begin{array}{l}\text { (a) Social } \\
\text { interaction/play, } \\
\text { (b) Social initiation, } \\
\text { (c) Responding to } \\
\text { social initiations }\end{array}$ & \\
\hline
\end{tabular}




\section{Appendix B: PEM and PND of Interventions}

Figure B-1. Interventions to Support Joint Attention

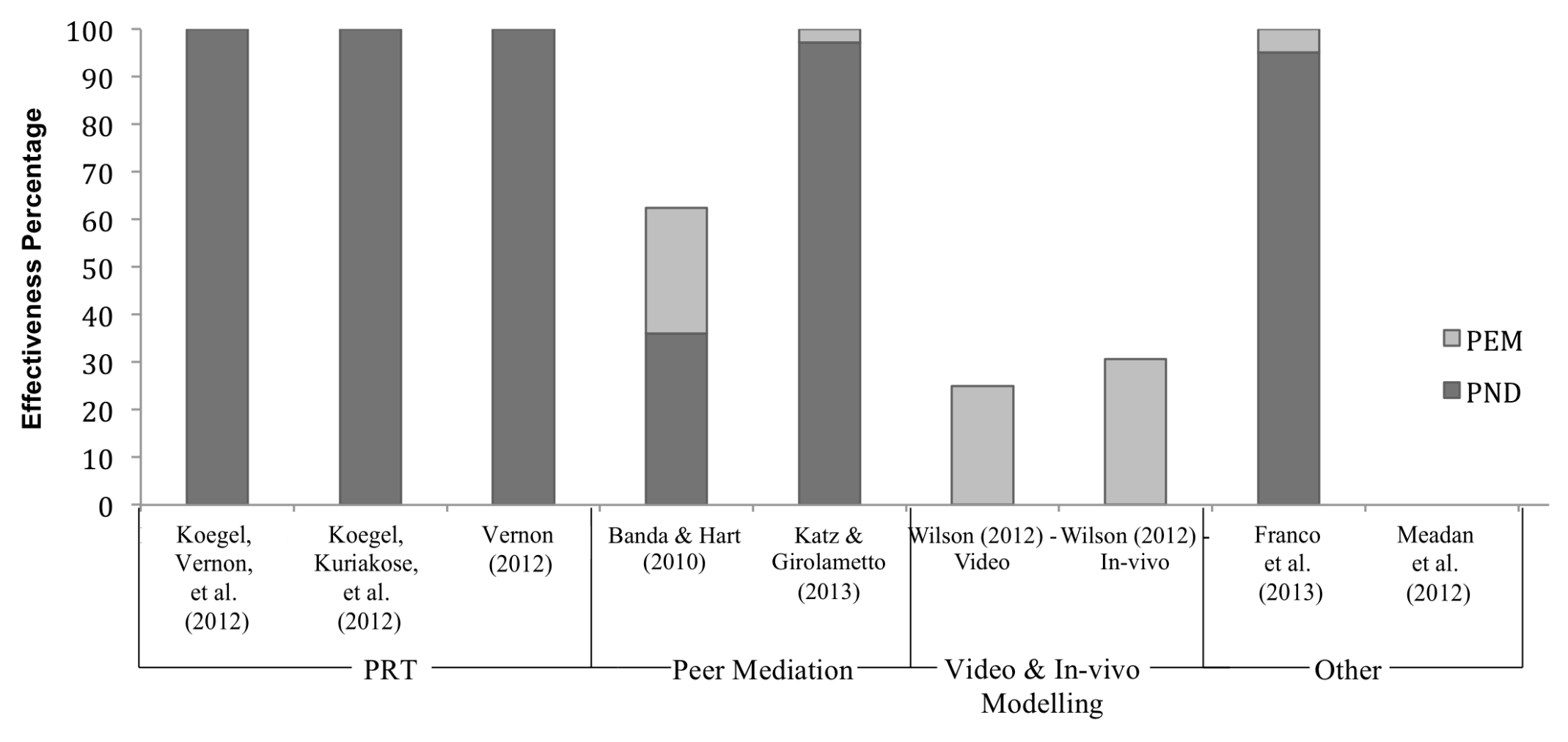

Studies and Independent Variables 
Appendix B, continued

Figure B-2. Interventions to Support Responding

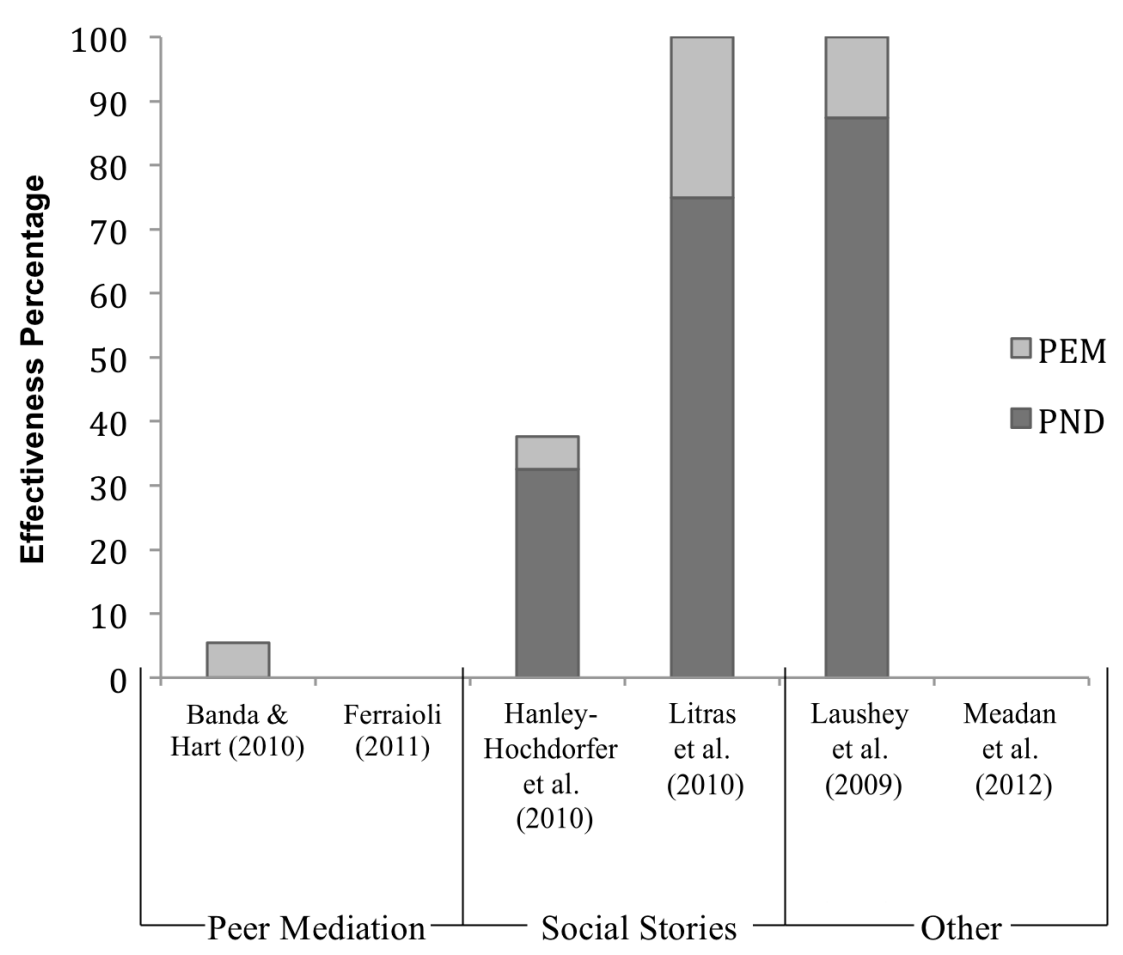

Studies and Independent Variables
Figure B-3. Interventions to Support Eye Contact

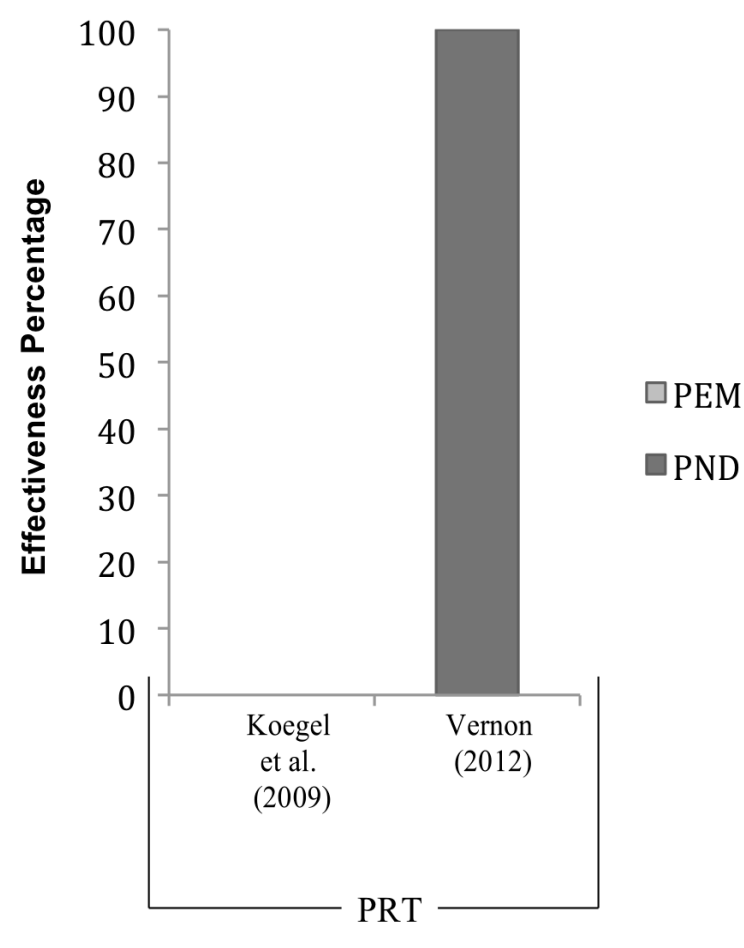

Studies and Independent Variables 


\section{Appendix B, continued}

Figure B-4. Interventions to Support Initiating Interactions

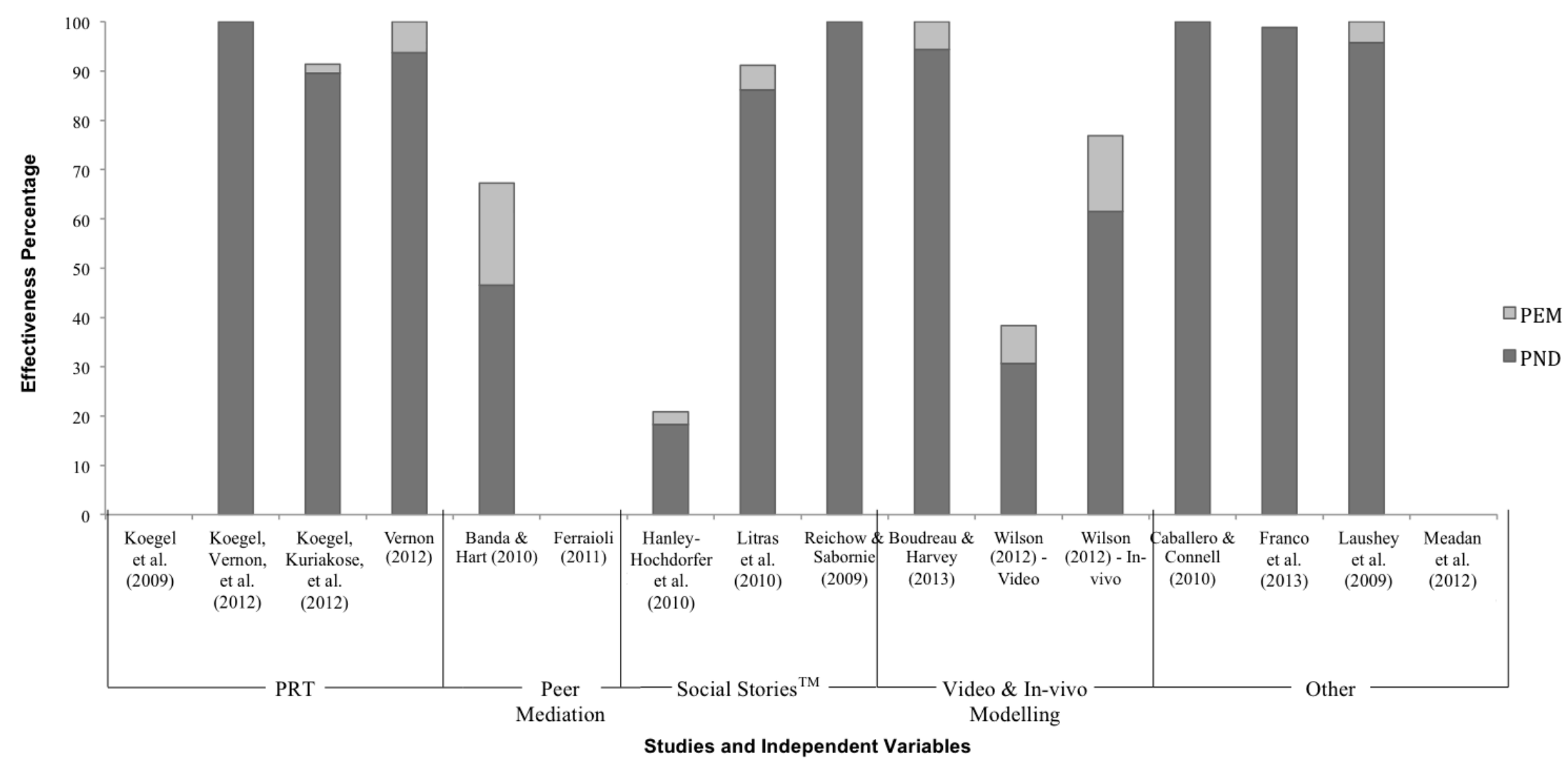




\section{Appendix C: Follow-up, Maintenance, and Generalization Summary}

\begin{tabular}{|c|c|c|}
\hline Study & Follow-up/Maintenance & Generalization \\
\hline \multicolumn{3}{|l|}{ Peer-Mediated } \\
\hline Ferraioli (2011) & $\begin{array}{l}\text { Follow-up: Responding behaviours maintained; Initiating } \\
\text { behaviours remained near baseline }\end{array}$ & - \\
\hline Katz \& Girolametto (2013) & Maintenance: Target behaviours maintained & - \\
\hline \multicolumn{3}{|l|}{$P R T$} \\
\hline Koegel, Kuriakose, et al. (2012) & Follow-up: Generalization assessed in 1 of 3 participants & $\begin{array}{l}\text { Target behaviours generalized in all } 3 \\
\text { participants }\end{array}$ \\
\hline Vernon (2012) & Follow-up: Generalization assessed & Target behaviours generalized \\
\hline \multicolumn{3}{|l|}{ Social Stories } \\
\hline Hanley-Hochdorfer et al. (2010) & $\begin{array}{l}\text { Follow-up: Similar results to intervention- return to } \\
\text { baseline }\end{array}$ & - \\
\hline Litras et al. (2010) & Follow-up: Target behaviours maintained & Target behaviours generalized \\
\hline Reichow \& Sabornie (2009) & $\begin{array}{l}\text { Maintenance: Cue cards used to maintain; target } \\
\text { behaviour maintained }\end{array}$ & - \\
\hline \multicolumn{3}{|l|}{ Video Modelling } \\
\hline Boudreau \& Harvey (2013) & $\begin{array}{l}\text { Maintenance: Target behaviour maintained in } 2 \text { of } 3 \\
\text { participants; } 1 \text { showed regression }\end{array}$ & - \\
\hline Wilson (2012) & $\begin{array}{l}\text { Maintenance: Target behaviours maintained in } 2 \text { of } 4 \\
\text { participants }\end{array}$ & - \\
\hline \multicolumn{3}{|l|}{ Others } \\
\hline Caballero \& Connell (2010) & Follow-up: Target behaviour maintained & Target behaviour generalized \\
\hline Franco et al. (2013) & Follow-up: Target behaviours maintained & - \\
\hline Laushey et al. (2009) & Follow-up: Target behaviours maintained & Target behaviours generalized \\
\hline
\end{tabular}

